Research, part of a Special Feature on Understanding the Vulnerability and Sustainability of Urban Social-Ecological Systems in the Tropics: Perspectives from the City of San Juan

\title{
Tourism and climate conditions in San Juan, Puerto Rico, 2000-2010
}

$\underline{\text { Pablo A. Méndez-Lázaro }}^{1}$, Jose J. Terrasa-Soler $^{2}$, Christian Torres-Peña $^{2}, \underline{\text { Paula Guzmán-González }}^{3}, \underline{\text { Sulaine Rodríguez }}^{3}$, Mariangely Alemán $^{3}$ and Tatiana Seguinot ${ }^{4}$

ABSTRACT. The general behavior of the tourism sector in Puerto Rico, with its marked seasonality, hints at a close relationship between tourism activities and climate conditions. Even if weather condition is only one of many variables considered by travelling tourists, climate conditions weigh heavily in the majority of the decisions. The effect of climate variability on the environment could be manifested in warmer temperature, heat waves, and changes in the frequency of extreme weather events, such as severe storms and hurricanes, floods, and sea level rise. These conditions affect different sectors of society, among them public health and the economy. Therefore, our research has two main objectives: to establish a tourism climate index (TCI) for Puerto Rico and to analyze if occupancy rates in hotels correspond to local weather conditions. Even though there are many other variables that could have positive or negative effects on tourism activities, results showed a significant association between occupancy rate in Puerto Rico and climate indexes. According to both TCI and the mean historical climate for tourism indexes, the most favorable months for tourism in Puerto Rico were February and March (winter), whereas the worst season was the end of August and the beginning of September (summer-fall). Although winter represents dry conditions and lower temperatures in San Juan, it also represents the highest occupancy rate during the years examined. In summer and fall, data showed high occupancy rates, yet climate conditions were not suitable; these months also correspond to the hurricane season. During this season, high relative occupancy rates responded to internal and local tourism patterns. It can therefore be assumed that until the climate-tourism relationship is well characterized, there is little hope of fully understanding the potential economic effects, detrimental or beneficial, of global climate change, not only on tourism in Puerto Rico, but on other economic sectors as well.

Key Words: climate variability; Puerto Rico; tourism; tourism climate index

\section{INTRODUCTION}

Even though tourism activity in Puerto Rico is only about $6 \%$ of its gross domestic product (GDP), tourism is still a key piece of the islands' economic development strategy (Terrasa-Soler 2012). The Puerto Rico Tourism Company (PRTC), the government agency in charge of tourism development, spends in excess of US\$50 million per year in marketing and promotion, which is significantly more than most other destinations in the Caribbean (CTO 2005).

Traditional marketing of Puerto Rico as a tourism destination has focused on creating tantalizing images. The role of visual seduction has been and continues to be important: a tropical beach scene amid the harsh winter of Times Square has been, and still is, a powerful advertising hook. An important part of that scene or image is definitively the pleasant climate. What Puerto Rico and other Caribbean islands sell to tourists from temperate zones is a pleasant climate in the midst of winter; the opportunity to travel to a close, beautiful location and get relief from the winter climate. The reality of this dynamic is reflected in the fact that the high season for tourism in Puerto Rico and the Caribbean corresponds to the winter season in the Northern Hemisphere. This dynamic is particularly important to Puerto Rico because approximately $90 \%$ of its tourists come from the United States, with most coming during the winter and from the northeastern corridor of the United States (Terrasa-Soler 2012).

In addition to marketing strategies, the availability of real-time weather information via the Internet, and the increasing tendency of tourists to make last-minute travel plans suggest that climate might influence the behavior of tourists in selecting destinations and making travel plans. The relationship between climate and tourism has been explored for some locations (Morgan et al. 2000, Amelung and Viner 2006, Yu et al. 2009a, Lin and Matzarakis 2011). A distinction has to be made, however, between local weather patterns and long-term, global climate change. Global climate change and its potential effects on tourism have also been studied (Uyarra et al. 2005, Perch-Nielsen 2008, Hein et al. 2009, Lewis-Bynoe et al. 2009, Moore 2010). We specifically explore the relationship between local weather patterns and tourism activity in Puerto Rico. This knowledge will be useful in the future to assess the relationship between global climate change and tourism activity in the Puerto Rican islands.

The interface between climate and tourism is multifaceted and complex, as climate represents both a vital resource to be exploited and an important limiting factor that poses risks to be managed by the tourism industry and tourists alike (Scott and Lemieux 2010). Weather and climate information are of interest to tourists and the tourism industry, particularly before and during the vacation period (Matzarakis 2006). In this context, climate variation or oscillations may provoke shifts in tourist flows, with large economic implications (Amelung and Moreno 2009). Therefore, it can be expected that climate change could affect the relative attractiveness of destinations and hence the motive for international tourists to leave their country of origin (Matzarakis 2006, Gandomkar and Mohseni 2011).

The general seasonality of the tourism sector in Puerto Rico has been widely established (Terrasa-Soler 2012) and its close 
relationship to climate seems evident. Although the extended holiday season in Puerto Rico (December-January) attracts a lot of family and friends to the islands, exit interview polls suggest, however, that a significant portion of visitors come to enjoy shopping, nightlife, and outdoor activities in the context of a pleasant climate (Rafael Silvestrini, PRTC, personal communication). What is this pleasant climate that tourists come looking for?

'Pleasant climate' has been defined in other studies as "slightly warm with clear skies or scattered clouds" (de Freitas et al. 2008:404) and 'slightly warm' has been defined as temperatures around $21^{\circ} \mathrm{C}$ (Lise and Tol 2002). Of course, comfort and what is perceived as 'pleasant climate' go well beyond temperature and cloud cover to include humidity, precipitation, sunshine duration, and so forth. In addition to this psychological aspect of climate, rain, extreme temperatures, or the threat from an approaching storm can impede touristic activities or temporarily change the desirability of a destination. To integrate the various components of climate, indexes have been developed. Mieczkowski (1985), for example, developed the tourism climate index (TCI), which is based on the notion of human comfort, as a weighted average of seven climatic variables to include various measures of temperature, humidity, precipitation, sunshine, and wind speed. The TCI ranges from -20 to 100 (ideal). De Freitas et al. (2008) developed an index represented as thermal sensation, i.e., from very cold to very hot, that also includes several climatic variables; and Delgado Castro and Gálvez Soler (2012) developed the mean historical climate for tourism (MHC) index, which is an adaptation of the TCI.

In the 1960s and 1970s, systematic research was performed on the influence of climatic conditions on the physical well-being of humans (Amelung and Viner 2006, Amelung and Moreno 2009). Some of this research was applied to tourism activity and several countries around the world, such as Germany, Switzerland, Spain, Canada, Australia, Trinidad-Tobago, and Barbados, are now using the TCI in their tourism development strategies (Morgan et al. 2000, Yu et al. 2009b, Moore et al. 2010, Whittlesea and Amelung 2010, Ramezani Gourabi and Palic 2012).

Tourism demand or touristic activity, on the other hand, can be measured in several ways. Arrivals, hotel occupancy rates, and hotel room average daily rate are all common measures of touristic activity and demand. Of all the available measures of tourism activity, however, hotel occupancy rate is one of the most sensitive and immediate indicators of tourism demand in local markets (Jeffrey and Barden 2001, Hong 2010). We looked at average hotel occupancy rates (OCC) and several measures of climate to explore the relationship between climate and tourism in Puerto Rico. This relationship needs to be explored for a variety of reasons: to understand the response of tourists to climate in Puerto Rico, to plan for better economic performance in the local tourism sector, and to plan for the potential consequences of global climate change, among others.

\section{METHODS}

\section{Study area}

The territory of Puerto Rico covers an area of approximately $8940 \mathrm{~km}^{2}$. It is an archipelago in the Caribbean Sea $\left(18^{\circ} 12^{\prime} 00^{\prime \prime} \mathrm{N}\right.$, $\left.66^{\circ} 32^{\prime} 00^{\prime \prime} \mathrm{W}\right)$. The average annual precipitation varies spatially between $4000 \mathrm{~mm}$ and $800 \mathrm{~mm}$ (Fig. 1), showing an average of $1752 \mathrm{~mm}$ (Méndez-Lázaro and Martínez 2012). Rainfall increases from the coasts to the center of the main island (Colón Torres 2009). The northern region is the rainiest, with $1550 \mathrm{~mm}$ of average annual precipitation.

The dry season begins in December and continues through the winter months to the end of March or the beginning of April, with intense rainfall at the end of April and the beginning of May. The rainfall typically decreases in June and July until the rainy season, August-October or November (Fig. 1).

\section{Database}

To identify the most favorable months for tourism activity related to regional life comfort and to analyze how climate variability could affect tourism in Puerto Rico, climate data sets (2000-2010) from the US National Climate Data Center (NCDC-NOAA; http://www.ncdc.noaa.gov/) and the National Weather Service in San Juan (http://www.weather.gov/) were used. Incomplete stations with a great lack of data were rejected. Daily data for temperature, precipitation, relative humidity, wind direction, and wind velocity from the San Juan International Airport Station were selected (R. Silvestrini, Puerto Rico Tourism Company, personal communication). Daily occupancy rate (percent) was obtained from the Puerto Rico Tourism Company (2000-2010).

To compare climate conditions and occupancy rates in Puerto Rico, two different tourism climate indexes were applied. The first index analyzed was the TCI developed by Mieczkowski (1985).

The tourism climate index implies a combination of seven climatic variables (Table 1). The TCI can be an effective tool to assess the supply and quality of climate resources for tourism (Lewis-Bynoe et al. 2009). Table 1 provides the weights and impacts of each of the variables used in the calculation of the index. The weights used in the equation are ultimately subjective, although they do have a basis in scientific knowledge. In the equation, the highest weight is given to the daytime comfort index because tourists are generally most active during the day. However, the amount of sunshine and the amount of precipitation are given the secondhighest weights, followed by daily thermal comfort and wind speed (Amelung et al. 2006). After summing the weighted individual components, the result is multiplied by two, so that the maximum TCI score is 100 .

$$
\mathrm{TCI}=8 * \mathrm{CID}+2{ }^{*} \mathrm{CIA}+4{ }^{*} \mathrm{R}+4{ }^{*} \mathrm{~S}+2 * \mathrm{~W}
$$

Where, CID means daytime comfort index, consisting of the mean minimum relative humidity $(\%)$ and the mean maximum air temperature $\left({ }^{\circ} \mathrm{C}\right)$, CIA the daily comfort index, consisting of the mean relative humidity $(\%)$ and the mean air temperature $\left({ }^{\circ} \mathrm{C}\right)$, and $\mathrm{R}$ the precipitation ( $\mathrm{mm}), \mathrm{S}$ the daily sunshine duration $(\mathrm{h})$, $\mathrm{W}$ the mean wind speed (m/s; Tang 2013). The calculated TCI ranged from -20 (impossible) to 100 (ideal), with further descriptive rating categories provided in Table 2.

Another method used in our research was the mean historical climate for tourism (MHC). The MHC is a new climate index developed by Delgado Castro and Gálvez Soler (2012). It is an adaptation of the first proposed method. 
Fig. 1. Annual rainfall distribution in Puerto Rico representing average monthly precipitation. The top three graphs show average monthly precipitation for weather stations at the San Juan Weather Service Forecasting Office, one near the City of Ponce, and another at Pico del Este peak in the Luquillo Mountains.
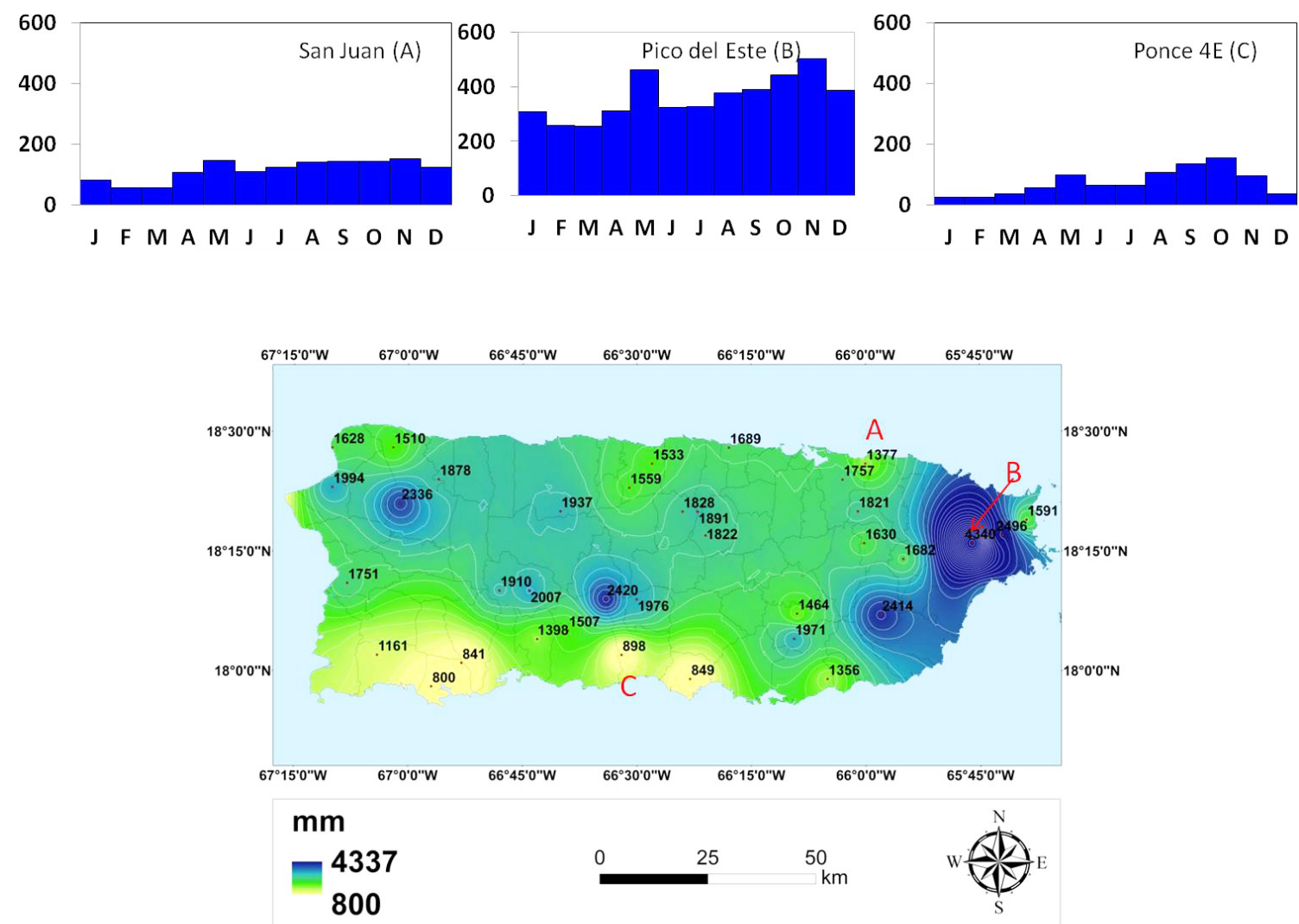

$\mathrm{MHC}_{\mathrm{i}}=$

$0.42\left(\right.$ TMed $\left._{\mathrm{i}}\right)+0.09\left(\mathrm{RH}_{\mathrm{i}}\right)+0.11\left(\operatorname{Precp}_{\mathrm{i}}\right)+0.38\left(\mathrm{Wwind}_{\mathrm{i}}\right)$

Where, Tmed $_{i}$ is mean temperature in Celsius, $\mathrm{RH}_{\mathrm{i}}$ is relative humidity, Prec $_{\mathrm{i}}$ is precipitation, and $\mathrm{W}$ wind $\mathrm{i}_{\mathrm{i}}$ is wind velocity. The subindex $i$ denotes the time period, in this case the months of the year. This new climate index has taken historical values between 18 and 40 units. The MHC ranged from 15 (excellent) to 40 (impossible; Table 3). What distinguishes the MHC from other climate indices is that the relative weights of the climate variables in the new index have been derived from the modeling and subjectivity of the researchers. This difference gives MHC more strength and precision to the index constructed (Delgado Castro and Gálvez Soler 2012).

\section{RESULTS AND DISCUSSION}

Average annual occupancy rates (OCC) in Puerto Rico, in 2000-2010, fluctuated between 66 and $87 \%$ distributed usually in four seasons. September had an occupancy rate of $66 \%$, the lowest during the study period, whereas February and March represented higher occupancy rates (Table 4). These results are consistent with the observed tourism patterns in Puerto Rico over the last 25 years.
According to both climate indexes, the most favorable months for tourism activities in Puerto Rico were the winter months, which have low temperatures and relatively little precipitation. February and March had high TCI values (73.82 and 66.55, respectively), and these high TCI values, more favorable climatic conditions for tourism, corresponded with the highest average monthly occupancy rates ( 86.98 and $86.96 \%$, respectively). February had the highest TCI and the highest average occupancy rates of the whole year. This corresponded to the dry season, which represents desirable weather, i.e., dryer, cooler weather, and climate comfort for tourists.

Taking into consideration that tourists came mainly from the northeastern coast of the United States, you could argue that this is advantageous because winter temperatures are much cooler at those latitudes. The opposite is true for the summer and early autumn, which shows high temperatures and abundant precipitation, as they get unfavorable index values. In addition, these seasons usually represent the hurricane season in the North Atlantic and therefore, could be seen as not suitable for the arrival of tourists and recreation. September has historically been the most active month for hurricanes in Puerto Rico and together with August, which is usually one of the hottest months, represented the lowest TCI values and the lowest OCC (Fig. 2). 
Table 1. Components of the Tourism Climate Index (TCI; ECLAC 2011).

\begin{tabular}{|c|c|c|c|}
\hline Subindex & Variables & Influence on TCI & Weight \\
\hline Daytime Comfort Index (CID) & $\begin{array}{l}\text { Maximum daily temperature; } \\
\text { Minimum daily relative humidity }\end{array}$ & $\begin{array}{l}\text { Represents thermal comfort when maximum } \\
\text { tourist activity occurs }\end{array}$ & $40 \%$ \\
\hline Daily Comfort Index (CIA) & $\begin{array}{l}\text { Mean daily temperature; } \\
\text { Mean daily relative humidity }\end{array}$ & $\begin{array}{l}\text { Represents thermal comfort over the full } 24 \\
\text { hour period, including sleeping hours }\end{array}$ & $10 \%$ \\
\hline Precipitation ( $\mathrm{R})$ & Total precipitation & $\begin{array}{l}\text { Reflects the negative impact that this element } \\
\text { has on outdoor activities and holiday enjoyment }\end{array}$ & $20 \%$ \\
\hline Sunshine (S) & Total hours of sunshine & $\begin{array}{l}\text { Positive impact on tourism (can be negative } \\
\text { because of the risk of sunburn and added } \\
\text { discomfort on hot days) }\end{array}$ & $20 \%$ \\
\hline Wind (W) & Average wind speed & $\begin{array}{l}\text { Variable effect depending on temperature } \\
\text { (evaporative cooling effect in hot climates rated } \\
\text { positively, whereas windchill in cold climates } \\
\text { rated negatively) }\end{array}$ & $10 \%$ \\
\hline
\end{tabular}

Fig. 2. A) Monthly Tourism Climate Index and monthly occupation rate. B) Occupation Rate and total rainfall in San Juan. 2000-2010.
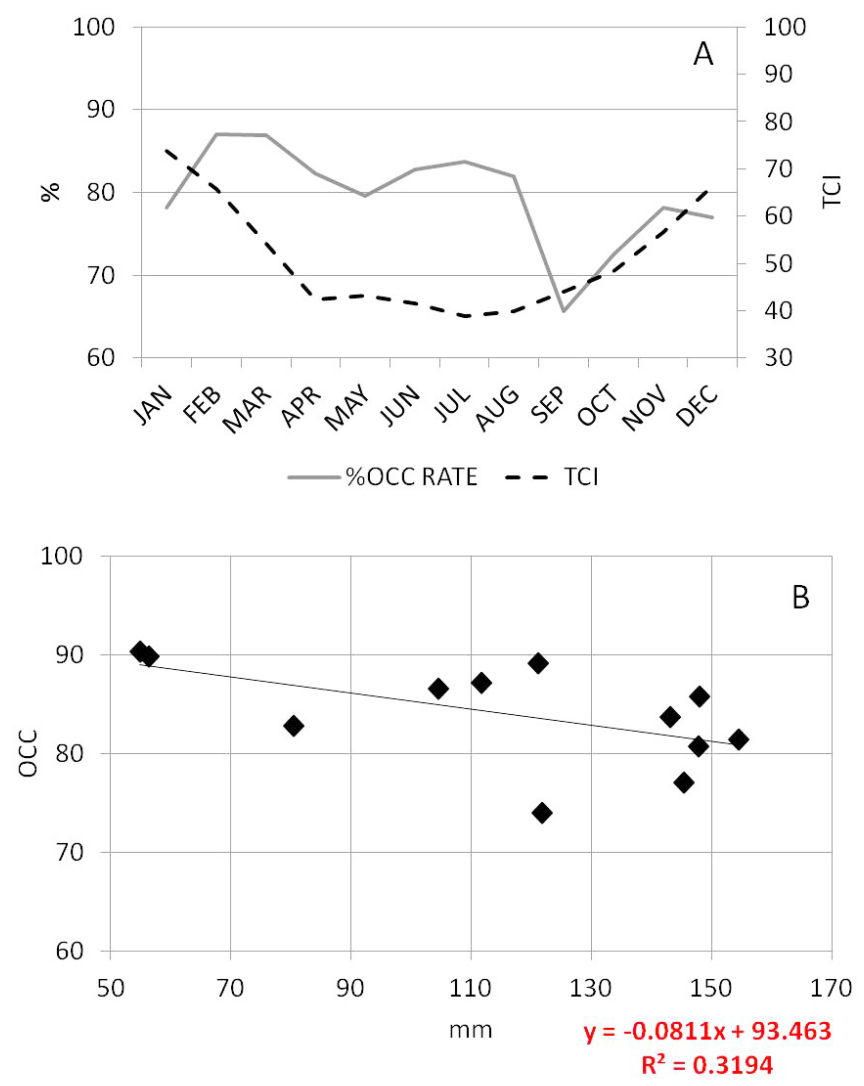

These results can be compared with Lewis-Bynoe et al.'s (2009) research, in which it was found that the TCI for several Caribbean islands was low, i.e., climate undesirable, during May-November, which coincided with higher temperatures and precipitation
Table 2. Rating categories for the Tourism Climate Index (TCI; ECLAC, 2011).

\begin{tabular}{cc}
\hline \hline TCI Score & Category \\
\hline 90 to 100 & Ideal \\
80 to 89 & Excellent \\
70 to 79 & Very good \\
60 to 69 & Good \\
50 to 59 & Acceptable \\
40 to 49 & Marginal \\
30 to 39 & Unfavorable \\
20 to 29 & Very unfavorable \\
10 to 19 & Extremely unfavorable \\
-20 to 9 & Impossible \\
\hline
\end{tabular}

Table 3. Mean Historical Climate for Tourism (MHC) scores and climate category (Delgado Castro and Gálvez Soler 2012).

\begin{tabular}{cc}
\hline \hline MHC Scores & Category \\
\hline 15 to 19 & Excellent \\
20 to 24 & Good \\
25 to 29 & Regular \\
30 to 34 & Adverse \\
35 to 40 & Impossible \\
\hline
\end{tabular}

during those months. That study, however, did not look at the relationship between climate and tourism demand. While studying the potential impacts of climate change on Caribbean tourism, Moore (2010) found that climate, as represented by the TCI, had a statistically significant impact on tourism demand, using data from 1980 to 2000. Lise and Tol (2002) had also found a close link between climate and holiday destination selection.

This tight relationship between good climatic conditions and high hotel occupancy rates in San Juan, Puerto Rico was further tested with a Pearson correlation. Results showed that TCI and average monthly occupancy rates were significantly correlated $(0.237, \mathrm{p}$ 
Table 4. Average Hotel Occupation Rate (OCC), Average Mean Historical Climate for Tourism (MHC), and Average Tourism Climate Index (TCI) for the study period.

\begin{tabular}{|c|c|c|c|c|c|c|c|}
\hline \multirow{2}{*}{\multicolumn{2}{|c|}{$\begin{array}{c}\text { Average Hotel } \\
\text { Occupation Rate } \% \\
\end{array}$}} & \multirow{2}{*}{\multicolumn{2}{|c|}{ Average MHC }} & & & \multicolumn{2}{|c|}{ Climate Variables } \\
\hline & & & & \multicolumn{2}{|c|}{ Average TCI } & Temperature & Rainfall \\
\hline JAN & 78.21 & 31.29 & Adverse & 66.73 & Good & 24.9 & 80.52 \\
\hline FEB & 86.98 & 24.65 & Favorable & 73.82 & Very good & 25.0 & 56.38 \\
\hline MAR & 86.96 & 24.90 & Favorable & 66.55 & Good & 25.5 & 54.97 \\
\hline APR & 82.30 & 37.43 & Impossible & 54.18 & Acceptable & 26.3 & 104.55 \\
\hline MAY & 79.63 & 36.96 & Impossible & 42.36 & Marginal & 27.2 & 148.03 \\
\hline JUN & 82.75 & 35.49 & Impossible & 43.36 & Marginal & 27.9 & 111.77 \\
\hline JUL & 83.67 & 37.07 & Impossible & 41.73 & Marginal & 28.1 & 121.17 \\
\hline AGO & 81.97 & 38.39 & Impossible & 38.55 & Unfavorable & 28.2 & 143.04 \\
\hline SEP & 65.60 & 37.83 & Impossible & 40.37 & Marginal & 28.1 & 145.38 \\
\hline OCT & 72.53 & 37.91 & Impossible & 43.77 & Marginal & 27.7 & 147.85 \\
\hline NOV & 78.12 & 38.60 & Impossible & 48.41 & Marginal & 26.6 & 154.50 \\
\hline $\mathrm{DEC}$ & 76.94 & 35.13 & Impossible & 56.23 & Acceptable & 25.6 & 121.79 \\
\hline
\end{tabular}

$<0.01)$. Similar results were obtained with the MHC: lower MHC values, i.e., better climatic conditions, also corresponded to higher occupancy rates in February and March. The MHC index, however, produced a more homogeneous climatic pattern, with most months of the year rated as 'bad' or 'adverse' climatic conditions. The TCI values obtained for Puerto Rico during the peak of the high season for tourism, i.e., January through March, were above 70, which was found by Amelung and Moreno (2009) to be ideal for the typical tourist activities of sightseeing and shopping. As we said earlier, tourist activity in Puerto Rico has been shifting precisely toward shopping, sightseeing, and nightlife, beyond the traditional 'sun and beach.'

The tourism sector is one of the largest and fastest growing global industries and is a significant contributor to national and local economies around the world (Scott and Lemieux 2010). Nevertheless, it is likely that tourism will be strongly affected by climate change because many tourist activities are dependent on weather conditions (Hein et al. 2009). Several studies and some research have indicated that climate change could impact the tourism sector (OMT 2007, da Cruz 2009, Hein et al. 2009, Buckley 2011). Long-term impacts resulting from a substantial and lasting alteration of the environment of a tourist destination may indirectly reduce its attractiveness (Sánchez and Dalle 2005, Xola Consulting 2009).

Many factors contribute to the profile of tourists visiting Puerto Rico. The significant population migration of Puerto Ricans that occurred in the 1950s and 1960s, mainly toward the eastern half of the United States, assures an almost constant flow of visitors to Puerto Rico, particularly during the holiday season. As the business and leisure tourism sectors developed, Puerto Rico saw an easy market in the eastern seaboard of the United States, given the density of air service that already existed to and from cities favored by Puerto Ricans that migrated to the United States, e.g., New York, Boston, Philadelphia, and, later on, Orlando. Although visits from family and friends to the islands are important, proportionately, the leisure and business travel markets offer greater economic benefits to Puerto Rico (TerrasaSoler 2012).
Even though tourism will not only respond to local climate conditions, the desirable weather conditions during winter in Puerto Rico can be at risk with increased climate variability and climate change. According to Méndez-Lázaro and Martínez (2012), rainfall patterns over the islands are changing, as is temperature. There is evidence that temperatures are increasing in Puerto Rico, and rainfall has shown a slight change in seasonality. In the winter months, monthly rainfall is also increasing. It is also expected that temperature will rise around the globe (Solomon et al. 2007). These patterns can make conditions unfavorable for certain tourism activities, which in turn could represent an impact on this economic sector in Puerto Rico if conditions in the northeastern United States became more suitable for tourism activities.

Moreover, there is a global concern that climate change will make certain environments more vulnerable and will potentially have an impact on economic activities related to tourism. Other regional climatic modeling results point to an acceleration of the hydrologic cycle in a warmer climate with potentially large impacts on the frequency of extreme events (Méndez-Lázaro 2012). All these climatic changes can affect places/destinations for tourists to visit. Globally, tourists prefer a temperature of $21^{\circ}$ C, i.e., average of the hottest month of the year, at their choice of holiday destination (Lise et al. 2002). It is highly likely that most of these direct effects of climate change, and their subsequent indirect effects, would have an impact on the Caribbean as well.

The marketing efforts that Puerto Rico has put traditionally out cater to North Americans wanting some relief from the winter and looking for a close location. Puerto Rico has matured as a destination, and although originally offering simply 'sun and beach,' that offer is now complemented by an active culinary, shopping, nightlife, and cultural scene. In fact, according to the most recent traveler's exit polls, most tourists now come to Puerto Rico because of its shopping opportunities, restaurants, and nightlife (Rafael Silvestrini, PRTC, personal communication). Even though these activities are less dependent on climate than beach going or hiking, we found that there is still a very close relationship between climate and tourism activity in Puerto Rico, as measured by hotel occupancy rates. 


\section{CONCLUSION}

The dataset studied showed strong hotel occupancy rates throughout most of the year. The summer months, despite being considered the low season, have high occupancy rates $(>80 \%)$. This is because Puerto Rico, unlike other Caribbean destinations, enjoys a healthy 'internal' tourism sector and a diversified offer throughout the year. Many Puerto Ricans prefer to spend their vacation time in Puerto Rico, and this contributes to the high occupancy rates in the summer. Our research shows that this internal market is not as sensitive to climatic factors as the 'external' market, which predominates during the months of November through March. It may be that other climatic variables, such as short-term rain patterns or extreme temperatures, influence the internal market more directly, but this aspect remains to be studied.

There is little doubt that climate and tourism are closely related in Puerto Rico. The more pleasant months of the year, which are the dryer and cooler February and March, correspond to the harshest winter conditions on the eastern seaboard of the United States, which is Puerto Rico's primary tourism market. This climatic resource, along with many other elements that make Puerto Rico an interesting destination, has been well exploited to drive tourism development, and economic development in general, on the islands. We need to study in more detail the tourism-climate dynamic in Puerto Rico and the Caribbean for many reasons, not the least of which is the potential economic effects of global climate change. It can be assumed that until the climate-tourism relationship is well characterized, there is little hope of fully understanding the potential economic impacts, detrimental or beneficial, of global climate change on the Puerto Rican islands and their different economic sectors. Our research is a starting point.

Responses to this article can be read online at: http://www.ecologyandsociety.org/issues/responses. $\mathrm{php} / 6380$

\section{Acknowledgments:}

We gratefully acknowledge the collaboration of Rafael Silvestrini, from the Puerto Rico Tourism Company's Statistics and Market Studies Division, for his help in providing the tourism information used in this research.

\section{LITERATURE CITED}

Amelung, B., and A. Moreno. 2009. Impacts of climate change in tourism in Europe. PESETA-Tourism study. European Commission Joint Research Centre Institute for Prospective Technological Studies. Office for Official Publications of the European Communities, Luxembourg City, Luxembourg. [online] URL: http://ftp.jrc.es/EURdoc/JRC55392.pdf

Amelung, B., and D. Viner. 2006. Mediterranean tourism: exploring the future with the tourism climatic index. Journal of Sustainable Tourism 14(4):349-366. http://dx.doi.org/10.2167/ jost549.0
Buckley, R. 2011. Tourism under climate change: will slow travel supersede short breaks? AMBIO 40:328-331. http://dx.doi. org/10.1007/s13280-010-0100-X

Caribbean Tourism Organization (CTO). 2005. Expenditure of national tourism organizations. Caribbean Tourism Organization, St. Michael, Barbados. [online] URL: https://www.onecaribbean. org/statistics/

Colón Torres, J. 2009. Climatología de Puerto Rico. Editorial de la Universidad de Puerto Rico, San Juan, Puerto Rico.

da Cruz, A. 2009. Cambio climático y turismo: posibles consecuencias en los destinos turísticos de Bahía, Brasil. Estudios y Perspectivas en Turismo 18:476-489. http://www.scielo.org.ar/ scielo.php? script $=$ sci arttext\&pid $=$ S1851-17322009000400007

de Freitas, C. R., D. Scott, and G. McBoyle. 2008. A second generation climate index for tourism (CIT): specification and verification. International Journal of Biometeorology 52 (5):399-407. http://dx.doi.org/10.1007/s00484-007-0134-3

Delgado Castro, A., and E. Gálvez Soler. 2012. Modelación de un nuevo índice climático para el turismo para el destino Cuba. $2^{\mathrm{a}}$ Convención Internacional de Estudios Turísticos. $2^{\circ}$ Simposio Internacional de Estudios de Turismo y Viajes. Ponencia T 05. Palacio de Convenciones. Universidad de La Habana, La Habana, Cuba.

Economic Commission for Latin America and the Caribbean (ECLAC). 2011. An assessment of the economic impact of climate change on the tourism sector in Montserrat. Economic Commission for Latin America and the Caribbean, Port of Spain, Trinidad and Tobago, West Indies.

Gandomkar, A., and N. Mohseni. 2011. Analysis and estimate of tourism climate index of Mazandaran Province, using the TCI model. Second international conference on business, economics and tourism management. International proceedings of economics development and research (IPEDR) 24(2). [online] URL: http:// www.ipedr.com/vol24/2-CBETM2011-M00002.pdf

Hein, L., M. J. Metzger, and A. Moreno. 2009. Potential impacts of climate change on tourism: a case study for Spain. Current Opinion in Environmental Sustainability 1:170-178. http://dx.doi. org/10.1016/j.cosust.2009.10.011

Hong, S. K. 2010. Hotel property characteristics and occupancy rate: examining super deluxe 1st class hotels in Seoul, Korea. International Journal of Tourism Sciences 10(3):25-47. [online] URL: http://ijts.tosok.or.kr/02 issue/abstract view.asp?IDX $=83$

Jeffrey, D., and R. R. D. Barden. 2001. An analysis of the nature, causes and marketing implications of seasonality in the occupancy performance of English hotels. Pages 119-140 in T. Baum and S. Lundtorp, editors. Seasonality in tourism. Pergamon, Oxford, UK.

Lewis-Bynoe, D., S. Howard, and W. Moore. 2009. Climate change and tourism features in the Caribbean. Tenth annual Sir Arthur Lewis institute of social and economic studies conference: navigating risks and building resilience in small states, Cave Hill, Barbados. [online] URL:http://mpra.ub.uni-muenchen.de/21470 
Lin, T.-P., and A. Matzarakis. 2011. Tourism climate information based on human thermal perception in Taiwan and Eastern China. Tourism Management 32:492-500 http://dx.doi.org/10.1016/ j.tourman.2010.03.017

Lise, W., and R. S. J. Tol. 2002. Impact of climate on tourist demand. Climatic Change 55(4):429-449. http://dx.doi. org/10.1023/A:1020728021446

Matzarakis, A. 2006. Weather- and climate-related information for tourism. Tourism and Hospitality Planning and Development 3(2):99-115. http://dx.doi.org/10.1080/14790530600938279

Méndez-Lázaro, P. 2012. Potential impacts of climate change and variability on public health. Journal of Geology and Geosciences 1:e104. http://dx.doi.org/10.4172/2329-6755.1000e104

Méndez-Lázaro, P., and J. Martínez. 2012. Tendencias hidroclimáticas y cambios en el paisaje de Puerto Rico. Editorial Académica Española, Saarbrüken, Germany.

Mieczkowski, Z. 1985. The tourism climatic index: a method of evaluating world climates for tourism. Canadian Geographer 29 (3):220-233. http://dx.doi.org/10.1111/j.1541-0064.1985.tb00365. $\underline{\mathrm{X}}$

Moore, W. R. 2010. The impact of climate change on Caribbean tourism demand. Current Issues in Tourism 13(5):495-505. http:// dx.doi.org/10.1080/13683500903576045

Morgan, R., E. Gatell, R. Junyent, A. Micallef, E. Özhan, and A. T. Williams. 2000. An improved user-based beach climate index. Journal of Coastal Conservation 6:41-50. http://dx.doi. org/10.1007/BF02730466

Organización Mundial del Turismo (OMT). 2007. Cambio climático y turismo: responder a los retos mundiales. Programa de las Naciones Unidas para el Medio Ambiente (PNUMA), Organización Mundial de Meteorología (OMM) y Organización Mundial del Turismo, Davos, Switzerland.

Perch-Nielsen, S. L. 2008. Climate change and tourism intertwined. Dissertation, ETH Zürich (Swiss Federal Institute of Technology), Zürich, Switzerland. http://dx.doi.org/10.3929/ ethz-a-005595352

Ramazani Gourabi, B., and M. Palic. 2012. Recognition of monthly human bioclimatic comfort with tourism climate index in Ramsar, South-West of Caspian Sea, Iran. Landscape and Environment 6(1):1-14.

Sánchez, A. B., and M. Dalle. 2005. Cambio climático. Efectos sobre el turismo. Instituto Sindical de Trabajo, Ambiente y Salud (ISTAS). Paralelo Edición, Madrid, Spain.

Scott, D., and C. Lemieux. 2010. Weather and climate information for tourism. Procedia Environmental Sciences 1:146-183. http:// dx.doi.org/10.1016/j.proenv.2010.09.011

Solomon, S., D. Qin, M. Manning, Z. Chen, M. Marquis, K. B. Avery, M. Tignor, and H. L. Miller. 2007. Climate change 2007: the physical science basis. Contribution of Working Group I to the Fourth Assessment Report of the Intergovernmental Panel on Climate Change. Cambridge University Press, Cambridge,
UK. [online] URL: http://www.ipcc.ch/publications and data/ publications_ipcc fourth_assessment_report_wg1_report the physical_science basis.htm http://dx.doi.org/10.1126/science.286.5437.87

Tang, M. 2013. Comparing the 'tourism climate index' and 'holiday climate index' in major European urban destinations. Thesis. University of Waterloo, Waterloo, Ontario, Canada. [online] URL: https://uwspace.uwaterloo.ca/handle/10012/7638

Terrasa-Soler, J. J. 2012. La gestión del turismo en Puerto Rico: entre lo público y lo Íntimo. Revista de la Escuela de Arquitectura de la Universidad de Puerto Rico (In)Forma 6:72-77.

Uyarra, M. C., I. M. Côté, J. A. Gill, R. R. T. Tinch, D. Viner, and A. R. Watkinson. 2005. Island-specific preferences of tourists for environmental features: implications of climate change for tourism-dependent states. Environmental Conservation 32:11-19. http://dx.doi.org/10.1017/S0376892904001808

Whittlesea, E., and B. Amelung. 2010. UK climate projections: national case study: what could tomorrow's weather and climate look like for tourism in the South West of England. South West Tourism, Exeter, UK.

Xola Consulting. 2009. Exploring the effects of climate change and sustainable development in the adventure tourism industry. Xola Consulting, Santa Fe, New Mexico, USA. [online] URL: $\underline{\text { http:// }}$ www.xolaconsulting.com/2009-xola-climate-change-adventure-tourism. pdf

Yu, G., Z. Schwartz, and J. E. Walsh. 2009a. Effects of climate change on the seasonality of weather for tourism in Alaska. Arctic 62(4):443-457. http://dx.doi.org/10.14430/arctic175

Yu, G., Z. Schwartz, and J. E. Walsh. 2009b. A weather-resolving index for assessing the impact of climate change on tourism related climate resources. Climatic Change 95:551-573. http://dx. doi.org/10.1007/s10584-009-9565-7 